\title{
Biochemical and Haematological Indices of Weanly Albino Rats Fed Millet and Maize
} Based Complementary Weaning Food

\author{
I.A. Umar ${ }^{1 *}$, Y. Saidu ${ }^{2}$, M. Lawal ${ }^{2}$ and S.A. Maigandi ${ }^{3}$ \\ ${ }^{1}$ Department of Biology Shehu Shagari College of education \\ ${ }^{2}$ Department of Biochemistry Usmanu Danfodiyo University Sokoto \\ ${ }^{3}$ Department of Animal Science, Usmanu Danfodiyo University, Sokoto. \\ *Author of Correspondence
}

\begin{abstract}
Malnutrition is a public health problem in Nigeria accounting for more than $50 \%$ of all childhood death. The current work evaluated some nutritional, biochemical and haematological indices of weanly albino rats fed millet and maize based complimentary weaning foods for 3 weeks. Two diets, MLMX and MZMX were compared on one hand and on the other with millet alone (MLA). Maize alone (MZA) diets was used as negative control and Frisocream (PC) as positive control.. The mineral profiles of the two groups of rats were significantly $(\mathrm{p}<0.05)$ different when compared. The growth rate of rats on these diets were not significantly $(\mathrm{p}<0.05)$ different and also compared well with the growth rate of rats on friscocream. The biochemical and haematological parameters indicated that the diets MLMX and MZMX may sustain effective growth and development in rats.
\end{abstract}

\section{INTRODUCTION}

Malnutrition is one of the major causes of high infant mortality in developing countries of the world, especially sub-saharan Africa (Philomena and Cecile, 1981). The most complex period is after weaning and generally in children below the age of two years (Walker 1990).

Solution to many of the underlying problem of under-nutrition lie outside the professional scope of nutritionist, as they involve economics, politics, food availability and distribution. At the local level, the causes of under-nutrition are also complex and may include inadequate or inappropriate weaning diets or poor nutritional status resulting from disease or illness caused by either improper timing of the introduction of the weaning foods or from infection arising from their contamination (Walker 1990). Provision of adequately nourishing weaning foods is critical to proper growth and development of the child(Walker 1990).

At age 4 months, the energy, protein and micro nutrients such as iron need of the child cannot be met solely from the breast milk (Walker, 1990). Making the inclusion of a complementary feed rich in these nutrients is imperative. Satisfying energy need is critical because of the protein sparing effect of energy(Walker 1990).
Problems of nutrition during the weaning period are complex and usually complicated by cultural, environmental and socio-economic factors (Fashakin and Ogunshola, 1982). Consiquently, the nature of food used for weaning in a given locality depends on the resources, culture and tradition, knowledge and technical know how of the community (Fashakin and Ogunshola, 1982).

In many villages and rural areas, weaning foods consist of starchy preparation which provide calories, and inadequate protein and other nutrients leading to protein energy mal nutrition (Fashakin and Ogunshola, 1982). The raw materials used in the preparation of these weaning foods are usually seasonal, and expensive in most of the communities (Fashakin and Ogunshola, 1982).

In Sokoto, Nigeria, millet is a staple food and is used extensively in the preparation of complementary weaning food; Just like any other cereal a diet prepared from millet may not be able to satisfy the nutritional needs of the weaned child. The implication of this to the overall development of the child cannot be over emphasized. In an earlier work (Umar, et al., 2008) the nutritional composition of complementary diets formulated from millet and 
maize based food stuffs was reported. The report showed that the nutrient composition of the diets were improved compared to millet alone and maize alone. The nutrient compositions of the diets were comparable to those of a commercially prepared weaning/complementary food, (Frisocream).

The current work reports the performance of millet and maize based complementary diets in weanly albino rats using nutritional, biochemical and haematological indices.

\section{MATERIALS AND METHOD}

Animals: Forty (40) Wister albino rats aged 3 weeks ( 21 days) were obtained from Biological Science Department, Usmanu Danfodiyo University, Sokoto. The rats were allowed to acclimatize for 3 days in well-ventilated cages. They were divided into five groups of 8 rats each (Groups A, B. C, D and E). Each of the rats was given an identification mark.

During the acclimatization period, the rats were allowed access to food and water ad libitun

Preparation of the Diets: Two different diets were prepared using locally sourced food stuffs. MLMX was composed of millet (60\%), groundnut $(16 \%)$, soy beans $(16 \%)$, crayfish (5\%) and palm oil (3\%) while MZMX was composed of all the components except that millet was substituted for maize. The groundnut was lightly fried and blanched to removed the "seed cover". The soy beans was soaked in boiled water for about 20 minutes and subsequently fried and blanched. MZMX was prepared in the same way. Substituting 60\% millet with $60 \%$ maize. Each of the diet was then ground using electric grinding machine. $3 \mathrm{~g}$ per $100 \mathrm{~g}$ of palm oil were added to each of the diets. The diets were compared with MLA

(100\% millet) and MZA (100\% maize). The MLA and MZA served as negative controls while Frisocream, a commercially prepared weaning food, was used as positive control diet.

Treatment of the Animals: Each group was provided with $100 \mathrm{~g}$ of the respective diet on daily basis for 21days, and the left over was collected each next morning and weighed. The animals were also provided with clean tap water ad libitun throughout the experimental period.

The rats were weighed before and after acclimatization and on weekly basis throughout the experimental feeding period. The mean weekly weight gain was computed.

The dropping of the animals were collected on daily basis, dried and weighed into labelled bottles. Two grammes of the faecal material were ground and used to estimate net protein utilization according to the McDonald et al., (1998) and Osborne et al., (1919).

At the end of the experimental period, each animal was sacrificed by decapitation. Blood sample were collected into (i) EDTA bottles for haematological analysis and (ii) plain bottles for biochemical parameters. After 10 minutes, the blood sample for biochemical parameters were centrifuged for 10 minutes. Serum was then carefully transferred with Pasteur pipettes into cleaned labeled sample bottles and stored at $20^{\circ} \mathrm{C}$ until required.

Biochemical Parameters Analysis: Serum total protein were estimated by the method of Henry and Stobel (1957). Serum albumin concentration was determined by BromoCresol Green (BCG) method (Doumas and Biggs, 1972). Globulin was determined by taking the difference between total protein and albumin (Turnwald and Barta 1989), while serum urea was estimated by diacetylmonoxine method (March, 1965). Serum mineral elements were analysed by flame photometry and atomic absorption spectrophotometry (Whiteside, 1979).

The haemoglobin $(\mathrm{Hb})$ content were analysed using cynomethemoglobin method (Drabkin and Austin 1932). Packed Cells Volume (PCV) and white blood cell (WBC) count were also done according to the methods of Linne and Ringsrud (1979).

Statistical Analysis: The data generated from the experiment were subjected to analysis of variance (ANOVA) using complete randomized design (CRD) as outlined by Steel and Torrie (1980). Significant differences between the means were indicated. Duncan's Multiple Range Test (DMRT) was used to separate the means (Duncan 1955)

\section{RESULTS AND DISCUSSION}

There was an increase in the average body weight gain in all the experimental rats showing that the rats were utilizing the diets during the experimental period (Table 1). 
Table 1:Net Protein Utilization and Weight Changes of Weanly Rats Fed Millet and Maize Based Complementary Diets

\begin{tabular}{lccccc}
\hline Groups & $\begin{array}{c}\text { Net protein } \\
\text { utilization } \\
\text { \% }\end{array}$ & $\begin{array}{c}\text { Average feed } \\
\text { intake }(\mathbf{g}) \text { per } \\
\text { week }\end{array}$ & $\mathbf{1}^{\text {st }}$ week & $\mathbf{2}^{\text {nd }}$ week & $\mathbf{3}^{\text {rd }}$ week \\
\hline MLMX & $55.50^{\mathrm{a}} \pm 2.5$ & $49.10^{\mathrm{a}} \pm 7.0$ & $61.35^{\mathrm{a}} \pm 1.7$ & $81.57^{\mathrm{a}} \pm 2.2$ & $95.77^{\mathrm{a}} \pm 1.9$ \\
MZMX & $50.76^{\mathrm{a}} \pm 2.2$ & $48.25^{\mathrm{a}} \pm 0.0$ & $58.41^{\mathrm{a}} \pm 1.2$ & $78.66^{\mathrm{a}} \pm 1.8$ & $94.76^{\mathrm{a}} \pm 2.4$ \\
MLA & $27.27^{\mathrm{b}} \pm 3.6$ & $45.59^{\mathrm{a}} \pm 10.1$ & $62.21^{\mathrm{a}} \pm 2.4$ & $69.85^{\mathrm{b}} \pm 2.0$ & $73.18^{\mathrm{b}} \pm 1.6$ \\
MZA & $23.54^{\mathrm{b}} \pm 3.6$ & $35.21^{\mathrm{b}} \pm 5.7$ & $46.22^{\mathrm{b}} \pm 0.8$ & $41.74^{\mathrm{b}} \pm 0.8$ & $21.62^{\mathrm{b}} \pm 0.5$ \\
PC & $63.30^{\mathrm{c}} \pm 1.5$ & $51.84^{\mathrm{a}} \pm 9.1$ & $63.63^{\mathrm{a}} \pm 2.1$ & $84.02^{\mathrm{a}} \pm 2.6$ & $98.57^{\mathrm{a}} \pm 2.5$
\end{tabular}

Values are mean $\pm \mathrm{SD}, \mathrm{n}=8$; Values bearing different superscripts(a,b,c) differ significantly $(\mathrm{P}<0.05)$; MLA=Millet Alone Diet; MZA =Maize Alone Diet; MLMX=Millet Mixture Diet;; MZMX = Maize Mixture Die; PC = Friscocream Diet

A significant increase $(\mathrm{P}<0.05)$ in diet consumption was observed in rats on $\mathrm{PC}$ and MLMX than rat on MZMX diets. The food consumption pattern in the two experimental diets MLMX and MZMX showed that the rat fed on the MLMX diet consumed more food than those on the MZMX diet group. (Table 1). This has been reflected in the growth rate of the animals in the two set of experiment in which the rats on the MLMX diet showed a higher average growth rate than those on the MZMX diet (Table 1). The utilization of diets by the rats on MZMX group was significantly $(\mathrm{P}<0.05)$ slightly lower than that of MLMX group.

The average growth rate of the rats fed on MLMX diet was significantly $(\mathrm{P}<0.05)$ higher than the rats fed with MZMX diet. Rats fed with MLMX diet gained more weight than those fed with MZMX diet. This may be because MZMX diet contained low amount of lysine and tryptophan (Umar et al. 2008).

The increase growth rate on the rats fed with PC, MLMX and MZMX diets is significantly higher than the rats fed with MLA and MZA diets. This is because the PC, MLMX and MZMX diet were complemented with other protein, mineral and pro-vitamin A sources. However the poor growth rate of rats on MLA and MZA diets particularly the MZA diet group was due to the fact that maize contains low amount of protein (zein) (Akinrele, 1971). Goel et al., (1977) also reprted that animals fed with proteins deficient diets lost growth.

The of serum albumin showed slight significant $(\mathrm{P}<0.05)$ difference in all the groups when compared, while that of protein showed significant difference in animals that consumed MZMX than those on PC and MLMX diets. The rats on corresponding mixture diet were greater than rats on negative control diets, which is lower than the reference range. This may be due to decrease in the synthetic function of the liver. The serum urea of rats on MLMX and MZMX diet where not significantly $(\mathrm{P}<0.05)$ differend when compared, the rats on corresponding mixture diets were significantly $(\mathrm{P}<0.05)$ higher than the rats fed with $\mathrm{PC}$ diet. The serum globulin content of rats on MZMX and MLMX group was significantly $(\mathrm{P}<0.05)$ differend when compared to rats on PC diet, which may be an indication tha rats were free of infection. The albumin globulin ratio $(A G)$ of rats fed with MLMX, MZMX and PC diets were showed significantly differend $(\mathrm{P}<0.05)$, and are lower than in rats on MLA and MZA diets. 
Table 2:Some Serum Biochemical Parameters of Weanly Albino Rats Fed Millet and Maize-Based Complementary Diets

\begin{tabular}{lccccc}
\hline Groups & $\begin{array}{c}\text { Total } \\
\text { protein } \\
(\mathbf{g} / \mathbf{d l})\end{array}$ & $\begin{array}{c}\text { Albumin } \\
(\mathbf{g} / \mathbf{d l})\end{array}$ & $\begin{array}{c}\text { Globulin } \\
(\mathbf{g} / \mathbf{d l})\end{array}$ & $\begin{array}{c}\text { Albumin/Globin } \\
\text { ratio }\end{array}$ & $\begin{array}{c}\text { Urea } \\
(\mathbf{m m o l} / \mathbf{l})\end{array}$ \\
\hline MLA & $4.58 \pm 0.1^{\mathrm{a}}$ & $3.06 \pm 0.2^{\mathrm{a}}$ & $1.47 \pm 0.4^{\mathrm{a}}$ & $2.3 \pm 0.8^{\mathrm{a}}$ & $3.74 \pm 0.5^{\mathrm{a}}$ \\
MZA & $4.50 \pm 0.2^{\mathrm{a}}$ & $3.20 \pm 0.2^{\mathrm{a}}$ & $1.32 \pm 0.3^{\mathrm{a}}$ & $2.5 \pm 0.6^{\mathrm{a}}$ & $3.92 \pm 0.2^{\mathrm{a}}$ \\
MLMX & $6.28 \pm 0.2^{\mathrm{b}}$ & $4.49 \pm 0.3^{\mathrm{b}}$ & $1.81 \pm 0.3^{\mathrm{b}}$ & $2.46 \pm 0.3^{\mathrm{b}}$ & $5.82 \pm 0.6^{\mathrm{b}}$ \\
MZMX & $6.34 \pm 0.4^{\mathrm{b}}$ & $4.47 \pm 0.3^{\mathrm{b}}$ & $1.85 \pm 0.4^{\mathrm{b}}$ & $2.42 \pm 0.3^{\mathrm{b}}$ & $5.83 \pm 0.6^{\mathrm{b}}$ \\
PC & $6.24 \pm 0.2^{\mathrm{c}}$ & $4.57 \pm 0.1^{\mathrm{c}}$ & $1.75 \pm 0.4^{\mathrm{c}}$ & $2.61 \pm 0.1^{\mathrm{c}}$ & $4.16 \pm 0.2^{\mathrm{c}}$ \\
\hline
\end{tabular}

Values are mean $\pm \mathrm{SD}, \mathrm{n}=8$; Values bearing different superscripts(a,b,c) differ significantly $(\mathrm{P}<0.05)$; MLA=Millet Alone Diet; MZA =Maize

Alone Diet; MLMX=Millet Mixture Diet;; MZMX = Maize Mixture Die; $\mathrm{PC}=$ Friscocream Diet

However, the serum albumin, urea and globulin level are within the reference values reported for these parameters in the literatures (March, 1965; Doumas and Biggs, 1972). Rat fed on MLA and MZA diets recorded to lower serum protein level below the reference range.

The decrease in serum protein may be an indication of impaired synthetic function of the liver. Rapid decrease in serum protein can be seen in hepatitis owing to decreased synthesis and lower than normal protein levels may indicate cirrhosis (Henry and Stobel, 1957). Although the bioavailability of the mineral elements in the 2 diets were not studied, all the serum of rats fed with MLMX and MZMX diet were significantly $(\mathrm{P}<0.05)$ high in all the elements except $\mathrm{Fe}$ and $\mathrm{Zn}$ where as rats on MZMX diets have higher content of $\mathrm{Fe}$ and $\mathrm{Zn}$ than the rats on MLMX diet, (Umar et al., 2008) reported that MZMX diet contained greater amount of Fe and Zn than MLMX and PC diets.

Table 3: Some Serum Mineral Element Level of Weanly Albino Rats Fed Millet and Maize Based Complementary Diets (mg/l)

\begin{tabular}{lccccccc}
\hline Groups & $\mathbf{N a}$ & $\mathbf{K}$ & $\mathbf{C a}$ & $\mathbf{F e}$ & $\mathbf{M g}$ & $\mathbf{Z n}$ & $\mathbf{C u}$ \\
\hline MZA & $41.76 \pm 0.2^{\mathrm{a}}$ & $13.35 \pm 0.8^{\mathrm{a}}$ & $7.22 \pm 0.3^{\mathrm{a}}$ & $7.55 \pm 0.2^{\mathrm{a}}$ & $2.53 \pm 0.4^{\mathrm{a}}$ & $0.25 \pm 0.5^{\mathrm{a}}$ & $0.66 \pm 0.1^{\mathrm{a}}$ \\
MLA & $94.68 \pm 0.7^{\mathrm{b}}$ & $19.70 \pm 0.1^{\mathrm{b}}$ & $10.27 \pm 0.2^{\mathrm{b}}$ & $7.05 \pm 0.3^{\mathrm{b}}$ & $2.79 \pm 0.7^{\mathrm{b}}$ & $0.10 \pm 0.1^{\mathrm{b}}$ & $0.42 \pm 0.2^{\mathrm{b}}$ \\
MZMX & $130.68 \pm 0.2^{\mathrm{b}}$ & $27.23 \pm 0.1^{\mathrm{c}}$ & $8.35 \pm 0.1^{\mathrm{a}}$ & $8.38 \pm 0.4^{\mathrm{b}}$ & $2.33 \pm 0.2^{\mathrm{a}}$ & $0.93 \pm 0.1^{\mathrm{c}}$ & $0.42 \pm 0.2^{\mathrm{b}}$ \\
MLMX & $144.36 \pm 0.7^{\mathrm{c} . \mathrm{d}}$ & $33.26 \pm 0.2^{\mathrm{d}}$ & $11.81 \pm 0.2^{\mathrm{b}}$ & $6.41 \pm 0.2^{\mathrm{c}}$ & $4.28 \pm 0.1^{\mathrm{b}}$ & $0.36 \pm 0.5^{\mathrm{d}}$ & $0.75 \pm 0.4^{\mathrm{a}}$ \\
PC & $151.56 \pm 0.2^{\mathrm{d}}$ & $34.23 \pm 0.6^{\mathrm{d}}$ & $8.76 \pm 0.1^{\mathrm{a}}$ & $5.53 \pm 0.3^{\mathrm{d}}$ & $2.44 \pm 0.1^{\mathrm{a}}$ & $0.18 \pm 0.1^{\mathrm{c}}$ & $0.15 \pm 0.3^{\mathrm{c}}$
\end{tabular}

Values are mean $\pm \mathrm{SD}, \mathrm{n}=8$; Values bearing different superscripts(a,b,c) differ significantly $(\mathrm{P}<0.05)$; MLA=Millet Alone Diet; MZA =Maize Alone Diet; MLMX=Millet Mixture Diet;; MZMX = Maize Mixture Die; PC = Friscocream Diet 
The $\mathrm{Hb}$ values for rat fed on MLMX and MZMX diet groups differ significantly $(\mathrm{P}<0.05)$ when compared, and slightly close to the rats on PC diets The Hb levels of rats on PC, MLMX and MZMX diet were within the range of (12.0 $-17.5 \mathrm{~g} / \mathrm{dl}$ ) reported in the literature (Bucklan et al., 1981).

The higher $\mathrm{Hb}$ levels recorded for rats fed on PC, MLMX and MZMX diets may be due to the higher content of iron in the food component. Rats fed on MLA and MZA diets had comparatively lower Hb levels. This is in accord with the report by (Umar, et al, 2008).
All the groups were normal and fall within the value 31 - 43\% (Buckland et al., 1981).

The PCV values for rats fed on MLMX and MZMX diets were significantly $(\mathrm{P}<0.05)$ higher than in those on PC diet. The values obtained fall within the normal range as reported by (Coles 1986). The increase in PCV values of rats fed MLMX and MZMX over MLA and MZA may be associated with improved nutritional components as reported by Swenson (1990).

TABLE 4:Haematological Indices Of Weanly Albino Rats Fed Millet And Maize Based Complementary Diets

\begin{tabular}{lcccccc}
\hline $\begin{array}{c}\text { Rats } \\
\text { Groups }\end{array}$ & $\begin{array}{c}\text { PCV } \\
(\boldsymbol{\%})\end{array}$ & $\begin{array}{c}\text { HB } \\
(\mathbf{g} / \mathbf{d l})\end{array}$ & $\begin{array}{c}\text { WBC } \\
\left.\mathbf{( 1 0}^{\mathbf{9 / L}}\right)\end{array}$ & $\begin{array}{c}\text { Grams } \\
(\boldsymbol{\%})\end{array}$ & $\begin{array}{c}\text { Lymp/mon } \\
\mathbf{0} \\
(\boldsymbol{\%})\end{array}$ & $\begin{array}{c}\text { PLT } \mathbf{x} \\
(\mathbf{1 0})\end{array}$ \\
\hline MLA & $35.40 \pm 0.9^{\mathrm{a}}$ & $11.03 \pm 0.2^{\mathrm{a}}$ & $10.36 \pm 0.4^{\mathrm{a}}$ & $49.66 \pm 1.5^{\mathrm{a}}$ & $48.66 \pm 1.5^{\mathrm{a}}$ & $121.23 \pm 7.1^{\mathrm{a}}$ \\
MZA & $35.93 \pm 0.3^{\mathrm{a}}$ & $11.40 \pm 0.4^{\mathrm{a}}$ & $16.26 \pm 0.3^{\mathrm{a}}$ & $59.65 \pm 1.5^{\mathrm{a}}$ & $34.01 \pm 1.2^{\mathrm{a}}$ & $97.10 \pm 1.5^{\mathrm{a}}$ \\
MLMX & $42.72 \pm 0.6^{\mathrm{b}}$ & $13.23 \pm 0.2^{\mathrm{b}}$ & $14.24 \pm 0.4^{\mathrm{b}}$ & $63.12 \pm 2.6^{\mathrm{a}}$ & $37.21 \pm 1.6^{\mathrm{a}}$ & $350.15 \pm 7.0^{\mathrm{c}}$ \\
MZMX & $40.33 \pm 0.7^{\mathrm{b}}$ & $12.30 \pm 0.3^{\mathrm{b}}$ & $14.46 \pm 0.7^{\mathrm{b}}$ & $60.31 \pm 1.5^{\mathrm{b}}$ & $60.30^{\mathrm{b}} \pm 1.2$ & $248.19 \pm 8.5^{\mathrm{b}}$ \\
PC & $45.86 \pm 0.4^{\mathrm{c}}$ & $16.06 \pm 0.6^{\mathrm{c}}$ & $12.46 \pm 0.3^{\mathrm{a}}$ & $39.42 \pm 1.0^{\mathrm{a}}$ & $42.66 \pm 1.0^{\mathrm{b}}$ & $157.20 \pm 4.3^{\mathrm{a}}$ \\
\hline
\end{tabular}

Values are mean $\pm \mathrm{SD}, \mathrm{n}=8$; Values bearing different superscripts(a,b,c) differ significantly $(\mathrm{P}<0.05)$; MLA=Millet Alone Diet; MZA =Maize Alone Diet; MLMX=Millet Mixture Diet; $\quad$ MZMX = Maize Mixture Die; $P C=$ Friscocream Diet

White Blood Cell Count (WBC) of rats fed corresponding mixture diets were significantly $(\mathrm{P}<0.05)$ higher than in rats fed on PC diets. The WBC count were within the normal values reported for rats (Jain, 1993).

The lymphocytes value of rats fed MZMX was significantly $(\mathrm{P}<0.05)$ higher than rats on $\mathrm{PC}$ and MLMX diets when compared. The values were within ranges reported by Coles (1986) and Jain (1993).

\section{REFERENCE}

Akinrele, I.A. and Edward. C. (1971). An assessment of the nutritive value of maize soya mixture, soy-ogi as a weaning food in Nigeria. Bri J. Nutri. 26:177-185.

Buckland, D.M., Hall, L., Morolem, A. and Wharle, B.F. (1981). A Guide to Animal Laboratory Technology, $1^{\text {st }}$ eds William Heinman Medical Book Ltd London 200.

Coles, E.H. (1986) Veterinary clinical pathology $\left(4^{\text {th }}\right.$ edition). W.B. Saunders company, Harcourt Brace Jovanovich, Inc.
Doumas, B.T. and Biggs H.G. (1972) Determination of Serum albumin: In standard methods of clinical chemistry (Cooper G.A.) Academic press Inc. New York 1:175.

Drabkin, D.L and Austin J.H 1932 Spectrophotometric studies:

Spectrophotometric constant for common hemoglobin derivatives in human, dogs and rabbits blood. J. bio.chem. 98:719

Duncan D.B. (1955) Multiple range and multiple F-test. Biometric, 11:1 - 42.

Fashakin J.B Ogunshola, F. (1982) The utilization of local foods in formulation of weaning foods: J. Trop Pediat 28:93 - 96.

Goel U., Kawantra B.L. and Bayaji S. (1977) Nutritional evaluation of a cauliflower lead protein concentrate by rat feeding. Journal of science food and agriculture 28: 786 - 790.

Henry, R.J. and Stobel, C. (1957). Determination of serum protein by Biuret reaction. Analytical Chem.. 92:1391

Jain N.C. (1993) Physiology of blood with some comments on responses to disease. Int. J. Animal Sci. 8: 195 - 231. 
Linne, J.J. and Ringsurd, K.K. (1979). Basic technique for medical laboratory $2^{\text {nd }}$ eds, $\mathrm{Mr}$ Graw-Hill book company New York. pp 191, 193, 196, 201 and 280.

March, A. (1965) Determination of serum urea using thiosemincarbazole. In: clinical chemical pathology mosby company St. louis USAP. 122.

McDonald, P. Edwards, R.A. Greenhalgh, J.F.D. and Morgan, C.A. (1998). Animal Nutrition $\left(4^{\text {th }}\right.$ ed). Pearson Education Limtd. Edinburgh. United Kingdom. p. 101

Osborne, T.B. Mendel, L.B. and Ferry, E.C. (1919). A method of expressing numerically the growth promoting value of proteins $J$. Biol. Chem. 37:223 - 229.

Philomena K.O. and Cecile H.E. (1981). A weaning food from locally grown grains in Nigeria: Growth and Nitrogen Retention in Rats. School of Human Ecology Howard
University Washington, D.C. 2005). Nutri Repts. Inter.24:1

Steel R.G.D and Torrie J.H.C. (1980) Principles and procedure of statistic McGraw Hill Book Co. Inc. New York.

Swenson, M.J. (1990) Physiological Properties cellular and chemical constituents of blood; Dukes Physiology of Domestic Animals $\left(10^{\text {th }}\right.$ ed.) Cornel University press, London.

Umar, I.A., Sa'id, Y. and Lawal, M. (2008). Comparative Study of Nutrient Composition of Millet and Maize Based complementary weaning food. Nig. J. Basic \& Appl. Sc 16(2): $282-287$

Walker, A.F. (1990): The Contribution of Weaning Foods to Protein-Energy Malnutrition. In: Nutri. Res. Rev. 3: 25-47

Whiteside, J.P. (1979) An introduction to atomic absorption spectrophotometry ( $1^{\text {st }}$ edition) pye unican ltd. Cambridge, England p. 1 30. 